\title{
Ammonium and Nitrate Shift the Spatial Distribution of Soil Bacterial Communities and Association Networks Along a Distance from Maize Roots in an Acidic Red Soil
}

\section{Hao Qing Zhang}

Institute of Soil Science Chinese Academy of Sciences

Xue Qiang Zhao ( $\sim$ xqzhao@issas.ac.cn )

Institute of Soil Science Chinese Academy of Sciences https://orcid.org/0000-0003-3120-3858

Yu Shi

Institute of Soil Science Chinese Academy of Sciences

Yuting Liang

Institute of Soil Science Chinese Academy of Sciences

Ren Fang Shen

Institute of Soil Science Chinese Academy of Sciences

\section{Research}

Keywords: maize, rhizobox, rhizosphere, ammonium, nitrate, bacterial community, bacterial network

Posted Date: July 16th, 2020

DOI: https://doi.org/10.21203/rs.3.rs-41492/v1

License: (c) (1) This work is licensed under a Creative Commons Attribution 4.0 International License.

Read Full License 


\section{Abstract}

Background: Ammonium $\left(\mathrm{NH}_{4}{ }^{+}\right)$and nitrate $\left(\mathrm{NO}_{3}{ }^{-}\right)$are two major inorganic nitrogen $(\mathrm{N})$ forms available for plant growth. Soil microbes affect the availability and transformation of these $\mathrm{N}$ forms in the rhizosphere, and this affects the N-use efficiency of plants. However, little is known about the responses of the rhizosphere bacterial community structure to $\mathrm{NH}_{4}{ }^{+}$and $\mathrm{NO}_{3}{ }^{-}$. Here, a rhizobox containing a root zone (root growing area) and various soil compartments $(0-0.5 \mathrm{~cm}, 0.5-1 \mathrm{~cm}, 1-2 \mathrm{~cm}, 2-4 \mathrm{~cm}$, and 4-9 $\mathrm{cm}$ from the root zone) was designed to investigate the spatial distribution of bacterial diversity, community structure, and co-occurrence patterns along a distance from maize (Zea mays L.) roots with the addition of ${ }^{15} \mathrm{~N}$-labeled $\mathrm{NH}_{4}{ }^{+}$or $\mathrm{NO}_{3}{ }^{-}$in an acidic red soil.

Results: Addition of $\mathrm{NH}_{4}{ }^{+}$and $\mathrm{NO}_{3}{ }^{-}$reduced soil bacterial diversity in the maize root zone. The structures of soil bacterial communities differed between $\mathrm{NH}_{4}{ }^{+}$and $\mathrm{NO}_{3}{ }^{-}$in the root zone and $0.5 \mathrm{~cm}$ away from the root zone. Soil pH was the major driver of bacterial community assembly during plant uptake of N. Maize roots recruited potentially beneficial acidophilic bacteria (e.g. Acidibacter, Burkholderia, and Catenulispora) under $\mathrm{NH}_{4}{ }^{+}$treatment, and recruited growth-promoting bacteria that prefer higher $\mathrm{pH}$ (e.g. Sphingomonas, Sphingobium, Azospirillum, and Novosphingobium) under $\mathrm{NO}_{3}{ }^{-}$treatment. In the Nfertilization treatments, the soil bacterial networks were more complex in the root zone and its adjacent 0.5-1 cm zone than in other soil compartments. The soil bacterial networks were more complex under $\mathrm{NH}_{4}{ }^{+}$treatment than under $\mathrm{NO}_{3}{ }^{-}$. More bacterial taxa in the networks responded positively and negatively to soil residual $\mathrm{NH}_{4}{ }^{+}$than to $\mathrm{NO}_{3}{ }^{-}$in all zones in the rhizobox.

Conclusions: The combined effects of the $\mathrm{N}$ form and the rhizosphere influenced the spatial patterns and co-occurrence network of soil bacterial communities at different distances from the maize root zone, mainly because of changes in soil pH during the uptake of $\mathrm{NH}_{4}{ }^{+}$and $\mathrm{NO}_{3}{ }^{-}$by maize roots. Regulating microbial communities by adjusting soil pH through $\mathrm{NH}_{4}{ }^{+}$and $\mathrm{NO}_{3}{ }^{-}$supply may be an environmentally friendly option for promoting soil microbial functions in intensively managed agro-ecosystems.

\section{Introduction}

The rhizosphere is an important biological hotspot where dramatic nutrient processes involving microbes occur [1]. The chemical, physical, and biological properties of soil in the rhizosphere are fundamentally affected by the presence and activity of plant roots [2]. Soil moisture and nutrients form gradients from the root surface to bulk soil due to the uptake of water and nutrients by plant roots $[3,4]$. The release of protons and ions from roots into the surrounding soil changes the $\mathrm{pH}$ of soil within 2 to $5 \mathrm{~mm}$ of the roots, depending on the soil's buffering capacity and the amount of ions released [4]. These microhabitat properties vary along a horizontal distance from the roots, and are major drivers of microbial community assembly $[5,6]$. Thus, the horizontal variations in these microhabitat properties may lead to gradients of microbial diversity from the root surface to bulk soil. Moreover, plant roots can recuit specific microbiota 
from surrouding soil by releasing root exudates $[7,8]$, leading to differences in microbiomes among the endosphere (root interior), rhizoplane (root surface), and rhizosphere (soil close to the root surface) [9]. The strength of the rhizosphere effect depends on the plant genotype, plant developmental stage, root morphology, abiotic stresses, and soil properties [10]. Investigating the shifts in microbial communities along a lateral gradient from the root surface to bulk soil can provide insights into the function of plant rhizosphere microbiomes. Although microbial community structures and co-occurrence patterns are known to differ between root-adhered soil and bulk soil [11, 12], less is known about continuous changes in microbial communities with increasing distance from plant roots.

Acidic soils (defined as $\mathrm{pH}<5.5$ ) are present at more than $50 \%$ of the cultivated and cultivable land area worldwide [13]. The cultivation of crops in acidic soils is important for agricultural production and food security. However, agricultural productivity in acidic soils is limited by a combination of stress factors [14]. Nitrogen $(\mathrm{N})$ is a major limiting essential nutrient for crop growth and productivity in acidic soils [15]. Large amounts of $\mathrm{N}$ fertilizers are applied to meet the growing food demands of the increasing population. However, the low $\mathrm{N}$-use efficiency of crops means that a large proportion of applied $\mathrm{N}$ escapes into the environment, causing negative effects such as water pollution, greenhouse gas emissions, and further soil acidification $[16,17]$. In this context, there is an urgent need to improve the $\mathrm{N}$ use efficiency of crops in acidic soils.

Ammonium $\left(\mathrm{NH}_{4}{ }^{+}\right)$and nitrate $\left(\mathrm{NO}_{3}{ }^{-}\right)$are the two main inorganic $\mathrm{N}$ sources available for plant growth. Their availability and transformation in the plant rhizosphere play important roles in improving $\mathrm{N}$-use efficiency and are mainly regulated by soil microbes [18]. Thus, investigating the assemblies of microbial groups along a lateral gradient from the plant root surface to bulk soil after the addition of $\mathrm{NH}_{4}{ }^{+}$and $\mathrm{NO}_{3}{ }^{-}$is key to understanding how the functions of soil microbes improve $\mathrm{N}$-use efficiency. The uptake of these two $\mathrm{N}$ forms by plants and their transformation in soils result in gradients of various environmental factors (such as nutrient concentrations and soil pH, porosity, and moisture) with increasing distance from the root surface [19]. Inputs of $\mathrm{NH}_{4}{ }^{+}$and $\mathrm{NO}_{3}{ }^{-}$may also lead to differences in plant growth and root morphology [20]. Thus, $\mathrm{NH}_{4}{ }^{+}$and $\mathrm{NO}_{3}{ }^{-}$may exert different effects on the assemblies of microbial groups along a gradient from the plant root surface to bulk soil because of the combination of changes in soil properties and rhizosphere effects. However, few studies have tried to quantify changes in microbial community composition and structure with increasing distance from roots of plants fertilized with $\mathrm{NH}_{4}{ }^{+}$ and $\mathrm{NO}_{3}{ }^{-}$.

Among modern crops, maize (Zea mays, L.) has the highest production and the greatest demands for $\mathrm{N}$ nutrition [21]. However, the annual maize yield continues to decrease because of $\mathrm{N}$-fertilizer-induced soil acidification in regions with acidic red soil in southern China [22,23]. Improving the $\mathrm{N}$-use efficiency of maize can reduce the amount of $\mathrm{N}$ fertilizer required, thereby alleviating soil acidification. There is increasing interest in rhizosphere microbial communities because of their potential to improve maize growth and $\mathrm{N}$-use efficiency. Previous studies have shown that microbial communities in the maize rhizosphere are affected by soil properties [24], plant genotype and age [25], and agricultural 
management methods [26]. For example, previous studies have shown that the addition of urea fertilizer leads to the enrichment of Bacillales, Nitrosomonadales, and Rhodocyclales in the maize rhizosphere because these orders are able to use urea as carbon or $\mathrm{N}$ sources [27], while Myxococcales and Burkholderiales are indicator orders in the maize rhizosphere under organic fertilization [26]. Although many studies have explored the interactive effect of agricultural management and plant selection on the microbial communities associated with maize roots [26], it is not enough to compare microbial communities only between rhizosphere soil and bulk soil under the same fertilization conditions. It is much more informative to investigate the continuous changes in soil microbial communities with increasing distance from maize roots under different $\mathrm{N}$-fertilizer treatments.

In this study, we used a rhizobox system to investigate the gradients in soil chemical properties, bacterial communities, and co-occurrence patterns with increasing distance from maize roots in an acidic red soil supplied with ${ }^{15} \mathrm{~N}$-labeled $\mathrm{NH}_{4}{ }^{+}$and $\mathrm{NO}_{3}{ }^{-}$. The results of this study provide insights into how the microbiome in the rhizosphere of maize plants responds to $\mathrm{NH}_{4}{ }^{+}$and $\mathrm{NO}_{3}{ }^{-}$.

\section{Materials And Methods}

\subsection{Experimental soil}

Acidic soil was obtained from farmland with underlying quaternary red earth at the Yingtan Red Soil Ecological Experiment Station ( $28^{\circ} 12^{\prime} \mathrm{N}, 116^{\circ} 55^{\prime} \mathrm{E}$ ), Jiangxi Province, China, in March 2019. Soil was collected from the upper 20-cm depth, air-dried, and sieved through a 2-mm sieve after removing roots and stones. The collected soil had a pH value of 4.8 , total $\mathrm{N}$ content of $1.18 \mathrm{~g} \mathrm{~kg}^{-1}, \mathrm{NH}_{4}{ }^{+}-\mathrm{N}$ content of $16.67 \mathrm{mg} \mathrm{kg}^{-1}, \mathrm{NO}_{3}{ }^{-} \mathrm{N}$ content of $14.94 \mathrm{mg} \mathrm{kg}^{-1}$, available $\mathrm{P}$ content of $18.36 \mathrm{mg} \mathrm{kg}^{-1}$, and available $\mathrm{K}$ content of $131.98 \mathrm{mg} \mathrm{kg}^{-1}$. These basic soil properties were determined as described below.

\subsection{Rhizobox design and sampling}

A rhizobox (length $\times$ width $\times$ depth, $19 \times 12 \times 18 \mathrm{~cm}$ ) was used to divide the soil fractions at different distances from maize roots (Fig. 1a). The rhizobox was divided into 11 compartments, which were separated by nylon cloth with a pore radius of less than $28 \mu \mathrm{m}$. This nylon mesh prevented the penetration of the root system, but allowed water, nutrients, and root secretions to pass through. Seeds were planted in the central compartment, which was designated as the root zone. There were five compartments on each side of the root zone, with widths of $0.5 \mathrm{~cm}, 0.5 \mathrm{~cm}, 1 \mathrm{~cm}, 2 \mathrm{~cm}$, and $5 \mathrm{~cm}$, respectively; these soil fractions were defined as $0-0.5 \mathrm{~cm}, 0.5-1 \mathrm{~cm}, 1-2 \mathrm{~cm}, 2-4 \mathrm{~cm}$ and $4-9 \mathrm{~cm}$ soil compartments from the root zone (Fig. 1a).

The experiment consisted of a control (CK, no $\mathrm{N}$ fertilizer) and two treatments: (1) the $\mathrm{NH}_{4}{ }^{+}$treatment, with $\mathrm{N}$ fertilizer as ${ }^{15} \mathrm{~N}$-labeled ammonium sulfate (20.18 atom \% excess), and (2) the $\mathrm{NO}_{3}{ }^{-}$treatment, with $\mathrm{N}$ fertilizer as ${ }^{15} \mathrm{~N}$-labeled sodium nitrate (30.15 atom \% excess). Both the $\mathrm{NH}_{4}{ }^{+}$and $\mathrm{NO}_{3}{ }^{-}$fertilizers were applied at the rate of $200 \mathrm{mg} \mathrm{N} \mathrm{kg}^{-1}$ soil (equivalent to $260 \mathrm{~kg} \mathrm{~N} / \mathrm{ha}$ in the field). In addition, 
phosphorus $(\mathrm{P})$ and potassium $(\mathrm{K})$ fertilizers were added as superphosphate and potassium chloride, respectively, to the control and both treatments at the rate of $100 \mathrm{mg} \mathrm{P} \mathrm{kg}^{-1}$ (equivalent to $130 \mathrm{~kg} \mathrm{P} / \mathrm{ha}$ in the field) and $200 \mathrm{mg} \mathrm{K} \mathrm{kg}^{-1}$ (equivalent to $260 \mathrm{~kg} \mathrm{~K} / \mathrm{ha}$ in the field). Each treatment had three replicates, so the experiment consisted of nine rhizoboxes. To ensure the homogeneous distribution of fertilizers in each rhizobox, the fertilizers and soils for each compartment were weighed accurately, mixed thoroughly, and placed separately in each compartment. Each rhizobox contained approximately $5 \mathrm{~kg}$ soil.

Maize (Zea mays L.) cv. 'Zhengdan 958' is a superior cultivar characterized by high and stable yield, and it is widely grown in China. Maize seeds were surface-sterilized with $10 \%$ hydrogen peroxide $\left(\mathrm{H}_{2} \mathrm{O}_{2}\right)$ for $20 \mathrm{~min}$ and then rinsed several times with deionized water. After germination on moist filter paper at $32{ }^{\circ} \mathrm{C}$ for $24 \mathrm{~h}$, five seeds were sown into the central compartment of each rhizobox on 18 April 2019. Maize seedlings were grown in a natural greenhouse located at the Institute of Soil Science, Chinese Academy of Sciences $\left(32^{\circ} 03^{\prime} \mathrm{N}, 118^{\circ} 47^{\prime} \mathrm{E}\right)$. The temperature range in the greenhouse was $25-34^{\circ} \mathrm{C}$ during the experiment. The plants were watered with deionized water every day to maintain sufficient moisture. The rhizoboxes were arranged randomly and their positions were changed every 3 days during the experiment to avoid growth differences due to variable lighting conditions.

The maize plants were harvested at the seedling stage on 26 May 2019, at 38 days after sowing. The harvested plants were separated into shoots and roots. After oven-drying at $75^{\circ} \mathrm{C}$ to constant weight, the dried plant materials were ground to pass a 0.149 -mm sieve for determination of total $\mathrm{N}$ content and ${ }^{15} \mathrm{~N}$ atom \% enrichment. Soil samples were immediately collected after the maize roots were removed from the soil. Soil fractions in each compartment were sampled separately. Soils in each compartment were sampled using a stainless steel blade, as described by Wang et al. [28]. Two soil samples collected at the same distance from the root zone (root growing area) at the right and left were mixed well to produce a composite sample. The collected soil samples were divided into two parts. One part was frozen immediately and stored at $-20^{\circ} \mathrm{C}$ until soil DNA exaction and soil $\mathrm{NH}_{4}{ }^{+}-\mathrm{N}$ and $\mathrm{NO}_{3}{ }^{-}-\mathrm{N}$ analyses. The other part was air-dried, then ground to pass through a 2-mm sieve for analyses of soil pH, available $\mathrm{P}$, and available $\mathrm{K}$ content, and to pass a $0.149-\mathrm{mm}$ sieve for determination of soil total $\mathrm{N}$ content and ${ }^{15} \mathrm{~N}$ atom \% enrichment.

\subsection{Soil and plant analyses}

Soil pH was measured using a pH meter (PB-21, Sartorius, Göttingen, Germany) in a soil:water solution (1:2.5). Soil $\mathrm{NH}_{4}{ }^{+}-\mathrm{N}$ and $\mathrm{NO}_{3}{ }^{-}-\mathrm{N}$ were extracted with $2 \mathrm{M} \mathrm{KCl}$, and measured using the indophenol blue colorimetry method and the dual wavelength spectrophotometry method, respectively. Soil available $P$ was extracted with $0.03 \mathrm{M}$ ammonium fluoride-hydrochloric acid, and determined using the molybdenum blue method. Soil available $\mathrm{K}$ was extracted with $1 \mathrm{M} \mathrm{CH}_{3} \mathrm{COONH}_{4}$ and measured by flame photometry (FP640, Shanghai Precision \& Scientific Instrument Inc., Shanghai, China). The total N contents of soil and plant materials were determined using a CNS elemental analyzer (Vario MAX, Elementar, Hanau, Germany), and their ${ }^{15} \mathrm{~N}$ atom \% enrichments were measured by elemental analyzer-isotopic ratio mass spectrometry (EA-IRMS) (Flash-2000 Delta V Advantage, Thermo Fisher, Waltham, MA, USA). 


\subsection{Soil DNA extraction, PCR amplification, and 16S rRNA gene sequencing}

Soil DNA was extracted from soil samples $(0.5 \mathrm{~g})$ using a DNA Extraction Kit (DNeasy PowerSoil Kit 100, Qiagen, Hilden, Germany) according to the manufacturer's instructions. The quality and quantity of DNA were checked using a NanoDrop-1000 instrument (NanoDrop Technologies, Wilmington, USA) and agarose gel electrophoresis. The extracted DNA was diluted to $1 \mathrm{ng} / \mu \mathrm{l}$ and then stored at $-20^{\circ} \mathrm{C}$ until subsequent processing.

Bacterial 16S rRNA genes were amplified from the diluted DNA by PCR using barcoded primers and Takara Ex Taq (Takara, Otsu, Japan). The V3-V4 variable regions of 16S rRNA genes were amplified with the primers 343F (5'-TACGGRAGGCAGCAG-3') and 798R (5'- AGGGTATCTAATCCT-3') for bacterial diversity analysis. Amplicons were separated and visualized by gel electrophoresis, purified with Agencourt AMPure XP beads (Beckman Coulter Inc., Brea, CA, USA), amplified by another round of PCR, and repurified with AMPure XP beads. The final amplicons were quantified using the Qubit dsDNA Assay Kit (Life Technologies, Carlsbad, CA, USA). Equal amounts of final products were pooled for subsequent sequencing at Shanghai OE Biotech. Co., Ltd. (Shanghai, China) using the MiSeq platform. The obtained sequences have been submitted to the NCBI Sequence Read Archive (SRA) under the accession number SRP250372.

\subsection{Processing of 16S rRNA gene data}

The high-throughput sequencing data were analyzed according to Chen et al. [29]. Briefly, after sequencing, paired-end reads were processed using Trimmomatic software [30] to detect and remove ambiguous bases and sequences with an average quality score below 20. After assembling the preprocessed reads using FLASH software [31], sequences were further denoised using QIIME software (version 1.8.0) [32]. Reads with ambiguous sequences, homologous sequences, or chimera, and reads shorter than $200 \mathrm{bp}$ were excluded from further analyses. After quality filtering, 1,527,237 high-quality sequences with 10,410 to 50,658 sequences per sample were obtained. The sequences were analyzed after resampling to the same depth $(8328,80 \%$ of minimum sequencing depth). Operational taxonomic units (OTUs) were generated using Vsearch software with a $97 \%$ similarity cut-off. The representative read for each OTU was selected using the QIIME package and annotated with reference to the Silva database (Version 123).

\subsection{Data analysis}

Two-way ANOVAs were carried out to evaluate the effect of the interaction between the $\mathrm{N}$ fertilizer form and distance from the root zone on soil properties and network topological features. One-way ANOVAs were performed to compare differences among soil compartments and $\mathrm{N}$-fertilizer treatments. Duncan's test was used for multiple comparisons $(p<0.05)$. The Kruskal-Wallis test was used for pair-wise comparisons to detect significant differences in the relative abundance of soil bacteria between $\mathrm{CK}$ and $\mathrm{NH}_{4}{ }^{+}, \mathrm{CK}$ and $\mathrm{NO}_{3}{ }^{-}$, and the $\mathrm{NH}_{4}{ }^{+}$and $\mathrm{NO}_{3}{ }^{-}$treatments $(p<0.05)$. Pearson's correlation coefficients were 
used to test the relationship between soil chemical properties and the relative abundance of specific genera. All the above analyses were performed using SPSS v.19 (SPSS Inc. Chicago, IL, USA) and R software v.3.6.1. The $\mathrm{N}$-recovery efficiency and amount of soil $\mathrm{N}$ derived from ${ }^{15} \mathrm{~N}$-labeled fertilizer (fertilizer-N) were calculated according to Zhang et al. [33].

Bacterial alpha diversity was calculated as estimated community diversity based on Shannon's index using QIIME software v.1.8.0. Bray-Curtis distances were calculated using the vegan package in $\mathrm{R}$ software v.3.6.1, and this package was also used for non-metric multidimensional scaling (NMDS) based on Bray-Curtis distance matrices. These analyses illustrated the clustering of different samples and further indicated bacterial community structure. Significant differences in bacterial community structure were tested by Permutational Multivariate Analysis of Variance (PERMANOVA) using the "adonis" function in the vegan package in R software. Significant correlations between community structures and soil properties were tested using Mantel tests. A redundancy analysis (RDA) was performed using $R$ software to detect relationships between community structures and soil properties.

\subsection{Association network analyses of bacterial communities}

The co-occurrence patterns of bacterial taxa were explored by network analysis. To reduce the complexity of the networks and to avoid bias due to the differences in OTU numbers, only the 500 most abundant OTUs in $\mathrm{CK}$ and the $\mathrm{NH}_{4}{ }^{+}$and $\mathrm{NO}_{3}{ }^{-}$treatments were included. Spearman's correlations between selected bacterial OTUs were calculated and the matrix was constructed using R software. A Spearman's correlation between two bacterial OTUs was considered statistically significant if the correlation coefficient ( $r$ ) was $>0.6$ and the $p$-value was $<0.05$. The $p$-values were adjusted using the Benjamini and Hochberg false discovery rate (FDR) test. All the significant correlations identified from pair-wise comparisons of bacterial OTUs were visualized in a correlation network, where each node represents one OTU, and each edge stands for a significant correlation between nodes. The topological features of bacterial networks were calculated and assigned to each sample using the igraph package in R software. The network complexity was calculated as the number of links per node according to Wagg et al. [34]. The networks were visualized using the Gephi platform.

\section{Results}

\subsection{Maize growth and distribution of ${ }^{15} \mathrm{~N}$-labeled fertilizer in plant-soil system}

Maize shoot dry weight was higher in the $\mathrm{NH}_{4}{ }^{+}$and $\mathrm{NO}_{3}{ }^{-}$treatments than in $\mathrm{CK}$, but did not differ significantly between the $\mathrm{NH}_{4}{ }^{+}$and $\mathrm{NO}_{3}{ }^{-}$treatments (Fig. $1 \mathrm{~b}$ ). The root dry weight did not differ significantly among treatments. The $\mathrm{N}$-recovery efficiency did not differ significantly between the $\mathrm{NH}_{4}{ }^{+}$ and $\mathrm{NO}_{3}{ }^{-}$treatments (Fig. 1c). The amount of soil residual fertilizer $\mathrm{N}$ showed a U-shaped pattern with increasing distance from roots in both the $\mathrm{NH}_{4}{ }^{+}$and $\mathrm{NO}_{3}{ }^{-}$treatments, and was higher in the $\mathrm{NH}_{4}{ }^{+}$ 
treatment than in the $\mathrm{NO}_{3}{ }^{-}$treatments across the soil compartments from $0.5-\mathrm{cm}$ to $4-\mathrm{cm}$ from the root zone (Fig. 1d).

\subsection{Soil chemical properties}

Soil residual fertilizer $\mathrm{N}$, soil $\mathrm{pH}$, total $\mathrm{N}, \mathrm{NH}_{4}{ }^{+}-\mathrm{N}$, and $\mathrm{NO}_{3}{ }^{-}-\mathrm{N}$ contents were significantly affected by both the $\mathrm{N}$ form and the distance from the roots. Soil available $\mathrm{K}$ content was significantly affected by only distance from the roots and available $\mathrm{P}$ was significantly affected by only the $\mathrm{N}$ form (Table S1). The interaction between $\mathrm{N}$ form and distance from the roots $(\mathrm{D} \times \mathrm{N})$ significantly affected soil residual fertilizer $\mathrm{N}$, soil $\mathrm{pH}, \mathrm{NH}_{4}{ }^{+}-\mathrm{N}$, and $\mathrm{NO}_{3}{ }^{-}-\mathrm{N}$, but did not affect total $\mathrm{N}$, available $\mathrm{K}$, and available $\mathrm{P}$.

In the $\mathrm{NO}_{3}{ }^{-}$treatment, soil $\mathrm{pH}$ was the highest in the root zone and the $0-0.5 \mathrm{~cm}$ soil compartment, and then decreased to similar levels to that in CK with increasing distance from the roots (Fig. 2a). Soil pH was the lowest in the $\mathrm{NH}_{4}{ }^{+}$treatment in all compartments of the rhizobox. Under both $\mathrm{N}$ treatments, the variations in soil total $\mathrm{N}$ were similar to those in soil residual fertilizer $\mathrm{N}$, and there was no significant difference in soil total $\mathrm{N}$ between the $\mathrm{NH}_{4}{ }^{+}$and $\mathrm{NO}_{3}{ }^{-}$treatments (Fig. 2b). The soil $\mathrm{NH}_{4}{ }^{+}-\mathrm{N}_{\text {contents were }}$ very low in all compartments of the rhizobox in $\mathrm{CK}$ and the $\mathrm{NO}_{3}{ }^{-}$treatments, but increased dramatically with increasing distance from the roots in the $\mathrm{NH}_{4}{ }^{+}$treatment (Fig. 2c). Soil $\mathrm{NO}_{3}{ }^{-}-\mathrm{N}$ contents were similar between the root zone and 0-4 cm soil compartments in the $\mathrm{NH}_{4}{ }^{+}$and $\mathrm{NO}_{3}{ }^{-}$treatments, but were dramatically increased in the 4-9 cm compartment in the $\mathrm{NO}_{3}{ }^{-}$treatment (Fig. $2 \mathrm{~d}$ ). The soil $^{-} \mathrm{NO}_{3}{ }^{-} \mathrm{N}$ contents were low in all compartments of the rhizobox in CK. In all treatments, the soil available $\mathrm{K}$ contents slightly decreased from the root zone to the $0-0.5 \mathrm{~cm}$ compartment and then increased with increasing distance from the roots (Fig. 2e). The soil available P contents were similar in all compartments in all treatments, and were generally higher in the $\mathrm{NH}_{4}{ }^{+}$treatment than in the $\mathrm{NO}_{3}{ }^{-}$ treatment (Fig. 2f).

\subsection{Bacterial alpha and beta diversity}

Compared with $\mathrm{CK}$, both the $\mathrm{NH}_{4}{ }^{+}$and $\mathrm{NO}_{3}{ }^{-}$treatments reduced the bacterial alpha diversity (Shannon's index) in root zone soil, but not in other soil compartments (Fig. 3a). With increasing distance from the roots, the bacterial alpha diversity tended to increase in the $\mathrm{NH}_{4}{ }^{+}$and $\mathrm{NO}_{3}{ }^{-}$treatments but not in CK. These results suggested that bacterial alpha diversity was inhibited by the combination of $\mathrm{N}$ fertilization and a rhizosphere effect.

The Bray-Curtis distance is used to indicate differences in microbial community structure between two treatments. The Bray-Curtis distances between $\mathrm{CK}$ and $\mathrm{NH}_{4}{ }^{+}, \mathrm{CK}$ and $\mathrm{NO}_{3}{ }^{-}$, and $\mathrm{NH}_{4}{ }^{+}$and $\mathrm{NO}_{3}{ }^{-}$were significantly higher in the root zone and $0-0.5 \mathrm{~cm}$ compartment than in the other soil compartments (Fig. 3b). This indicated a more pronounced effect of the $\mathrm{N}$ form on the formation of bacterial community structures within $0.5 \mathrm{~cm}$ of the root zone. The Bray-Curtis distance between the root zone and other soil compartments increased with increasing distance from the root zone, and it was higher in the $\mathrm{NH}_{4}{ }^{+}$and 
$\mathrm{NO}_{3}{ }^{-}$treatments than in $\mathrm{CK}$ (Fig. 3c). The rhizosphere effect was detected within $1 \mathrm{~cm}$ and $0.5 \mathrm{~cm}$ of the root zone under $\mathrm{NH}_{4}{ }^{+}$and $\mathrm{NO}_{3}{ }^{-}$treatment, respectively (Table S2). There were no significant variations in bacterial communities among different soil compartments in CK, indicating that the rhizosphere effect on the soil bacterial community was stimulated by $\mathrm{N}$ fertilizer. Therefore, in the NMDS analysis, two distinct groups formed as a result of the $\mathrm{N}$ form and rhizosphere effect (Fig. 3d).

The bacterial community composition was also influenced by the $\mathrm{N}$ form and rhizosphere effect (Fig. 3e). Gemmatimonadales was the dominant bacterial order in all soil compartments in CK. Under $\mathrm{NH}_{4}{ }^{+}$ treatment, Burkholderiales became the dominant bacterial order in the root zone, and its abundance decreased with increasing distance from the roots. Under $\mathrm{NO}_{3}{ }^{-}$treatment, Sphingomonadales became the dominant bacterial order in the root zone, and its abundance also decreased with increasing distance from the roots.

\subsection{Relationships between bacterial community structures and environmental variables}

The results of Mantel tests indicated that $\mathrm{pH}$ was the major driver of bacterial community assembly (Table S3). The RDA analysis revealed that the bacterial communities in the root zone and the $0-0.5 \mathrm{~cm}$ soil compartment were positively correlated with soil $\mathrm{pH}$ under $\mathrm{NO}_{3}{ }^{-}$treatment, and those in the 2-9 $\mathrm{cm}$ soil compartments were negatively correlated with soil pH under $\mathrm{NH}_{4}{ }^{+}$treatment (Fig. 4).

We identified the bacterial genera showing significant differences (Kruskal-Wallis test, $p<0.05$ ) in abundance between $\mathrm{CK}$ and $\mathrm{NH}_{4}{ }^{+}, \mathrm{CK}$ and $\mathrm{NO}_{3}{ }^{-}$, and the $\mathrm{NH}_{4}{ }^{+}$and $\mathrm{NO}_{3}{ }^{-}$treatments (Fig. 5). Compared with $\mathrm{CK}$, the $\mathrm{NH}_{4}{ }^{+}$treatment resulted in specific enrichment of four genera, Asticcacaulis, Acidibacter, Granulicella and Sinomonas within $0.5 \mathrm{~cm}$ of the maize root zone (Fig. 5a). The abundance of Acidibacter was negatively correlated with soil pH. In the $\mathrm{NO}_{3}{ }^{-}$treatment, four genera were specifically enriched within $0.5 \mathrm{~cm}$ of the maize root zone: Sphingomonas, Sphingobium, Pseudolabrys, and Azospirillum (Fig. 5b). The abundance of Sphingobium was positively correlated with soil pH. Comparing the $\mathrm{NH}_{4}{ }^{+}$and $\mathrm{NO}_{3}{ }^{-}$treatments, the specifically enriched genera within $0.5 \mathrm{~cm}$ of the root zone under $\mathrm{NH}_{4}{ }^{+}$ treatment were Burkholderia, Mucilaginibacter, Acidibacter, Leifsonia, Catenulispora, and Asticcacaulis, and their abundance was negatively correlated with soil pH (Fig. 5c). The specifically enriched genera within $0.5 \mathrm{~cm}$ of the root zone under $\mathrm{NO}_{3}{ }^{-}$treatment were Sphingomonas, Sphingobium, Pseudolabrys, Azospirillum, and Novosphingobium, and their abundance was positively correlated with soil pH.

\subsection{Bacterial co-occurrence patterns}

Multiple network topological features consistently showed that bacterial co-occurrence pattern was greatly affected by the $\mathrm{N}$ form and distance from the roots (Table 1 and Table S4). Compared with $\mathrm{CK}$, the $\mathrm{NH}_{4}{ }^{+}$treatment resulted in higher values for edge density, complexity, average clustering coefficient (agvCC), and degree of centralization of bacterial association networks in all soil compartments, and the 
$\mathrm{NO}_{3}{ }^{-}$treatment resulted in lower values for all of these topological features (Table 1). This indicated that the $\mathrm{NH}_{4}{ }^{+}$treatment resulted in the formation of more complex bacterial association networks, regardless of the distance from the maize roots. Under $\mathrm{NH}_{4}{ }^{+}$treatment, the edge density, degree of centralization, average clustering coefficient, and complexity had similar values in the root zone, $0-0.5 \mathrm{~cm}$, and $0.5-$ $1 \mathrm{~cm}$ soil compartments, and the values of these topological features were lower in outer soil compartments (Table 1). Under $\mathrm{NO}_{3}{ }^{-}$treatment, the values of these topological features were similar between the root zone and its adjacent $0.5 \mathrm{~cm}$ soil compartment, and were lower in the compartments further from the roots. Under $\mathrm{CK}$, the topological features showed no significant differences among the different soil compartments. This indicated that the bacterial association networks were more complex in the rhizosphere than in the bulk soil under both of the $\mathrm{N}$-fertilization treatments, but not in $\mathrm{CK}$. 
Table 1

Co-occurrence topological features of bacterial networks in different soil compartments in $\mathrm{CK}$ and under $\mathrm{NH}_{4}{ }^{+}$and $\mathrm{NO}_{3}{ }^{-}$treatments

\begin{tabular}{|c|c|c|c|c|c|c|c|}
\hline \multirow[t]{2}{*}{ Index } & \multicolumn{6}{|c|}{ Soil compartment } & \multirow[t]{2}{*}{ Average } \\
\hline & $\begin{array}{l}\text { Root } \\
\text { zone }\end{array}$ & $\begin{array}{l}0- \\
0.5 \mathrm{~cm}\end{array}$ & $\begin{array}{l}0.5- \\
1 \mathrm{~cm}\end{array}$ & $1-2 \mathrm{~cm}$ & $2-4 \mathrm{~cm}$ & $4-9 \mathrm{~cm}$ & \\
\hline & CK & & & & & & \\
\hline Nodes & $453 a$ & $462 a$ & $462 a$ & $461 a$ & $456 a$ & $449 a$ & 457 \\
\hline Edges & $5365 a$ & $5576 a$ & $5496 a$ & $5438 a$ & $5279 a$ & $5157 a$ & 5385 \\
\hline Edge density & $0.052 a$ & $0.052 a$ & $0.052 a$ & $0.052 a$ & $0.051 a$ & $0.051 a$ & 0.052 \\
\hline $\begin{array}{l}\text { Degree } \\
\text { centralization }\end{array}$ & $0.188 a$ & $0.194 a$ & $0.194 a$ & $0.193 a$ & $0.196 a$ & $0.203 a$ & 0.195 \\
\hline $\begin{array}{l}\text { Betweenness } \\
\text { centralization }\end{array}$ & $0.019 a$ & $0.018 a$ & $0.018 a$ & $0.018 a$ & $0.019 a$ & $0.019 a$ & 0.019 \\
\hline $\begin{array}{l}\text { Average clustering } \\
\text { coefficient }\end{array}$ & $0.349 a$ & $0.349 a$ & $0.347 a$ & $0.348 a$ & $0.343 a$ & $0.342 a$ & 0.346 \\
\hline Complexity & $11.82 \mathrm{a}$ & $12.01 \mathrm{a}$ & $11.90 a$ & $11.78 a$ & $11.53 a$ & $11.47 a$ & $11.76 a$ \\
\hline \multirow[t]{2}{*}{ Modularity } & $0.338 a$ & $0.346 a$ & $0.339 a$ & $0.330 a$ & $0.336 a$ & $0.314 a$ & 0.334 \\
\hline & $\mathrm{NH}_{4}^{+}$ & & & & & & \\
\hline Nodes & $402 b$ & $432 a b$ & $432 a b$ & $439 a$ & 432ab & 430ab & 428 \\
\hline Edges & $8850 a$ & $9624 a$ & $9496 a$ & $9075 a$ & $8649 a$ & $8369 a$ & 9011 \\
\hline Edge density & $0.110 a$ & $0.104 a$ & $0.102 a$ & $0.094 b$ & $0.093 b$ & $0.091 b$ & 0.099 \\
\hline $\begin{array}{l}\text { Degree } \\
\text { centralization }\end{array}$ & $0.362 a$ & $0.361 a$ & $0.364 a$ & $0.356 a b$ & $0.350 \mathrm{~b}$ & $0.346 b$ & 0.356 \\
\hline $\begin{array}{l}\text { Betweenness } \\
\text { centralization }\end{array}$ & $0.018 a$ & $0.018 a$ & $0.020 a$ & $0.018 a$ & $0.020 a$ & $0.018 a$ & 0.019 \\
\hline $\begin{array}{l}\text { Average clustering } \\
\text { coefficient }\end{array}$ & $0.437 a$ & $0.428 a$ & $0.425 a$ & $0.413 b$ & $0.420 b$ & $0.409 b$ & 0.422 \\
\hline Complexity & $21.97 a b$ & $22.28 \mathrm{a}$ & 21.97ab & $20.68 b c$ & $20.03 b c$ & $19.45 c$ & 21.06 \\
\hline Modularity & $0.224 b$ & $0.223 b$ & $0.239 \mathrm{~b}$ & $0.252 a b$ & $0.273 a$ & $0.245 a b$ & 0.243 \\
\hline
\end{tabular}

Different lowercase letters in each row indicate significant differences among various soil compartments $(p<0.05)$. 


\begin{tabular}{|c|c|c|c|c|c|c|c|}
\hline \multirow[t]{2}{*}{ Index } & \multicolumn{6}{|c|}{ Soil compartment } & \multirow[t]{2}{*}{ Average } \\
\hline & $\begin{array}{l}\text { Root } \\
\text { zone }\end{array}$ & $\begin{array}{l}0- \\
0.5 \mathrm{~cm}\end{array}$ & $\begin{array}{l}0.5- \\
1 \mathrm{~cm}\end{array}$ & $1-2 \mathrm{~cm}$ & $2-4 \mathrm{~cm}$ & $4-9 \mathrm{~cm}$ & \\
\hline Nodes & $432 c$ & $464 a$ & $455 a b$ & $447 \mathrm{bc}$ & $451 a b$ & $446 \mathrm{bc}$ & 449 \\
\hline Edges & $4166 a b$ & $4616 a$ & $4121 b$ & $3898 b$ & $3913 b$ & $3879 b$ & 4099 \\
\hline Edge density & $0.045 a$ & $0.043 a$ & $0.040 \mathrm{~b}$ & $0.039 b$ & $0.039 \mathrm{~b}$ & $0.039 b$ & 0.041 \\
\hline $\begin{array}{l}\text { Degree } \\
\text { centralization }\end{array}$ & $0.175 a$ & $0.160 a$ & $0.138 b$ & $0.131 b$ & $0.128 \mathrm{~b}$ & $0.126 b$ & 0.143 \\
\hline $\begin{array}{l}\text { Betweenness } \\
\text { centralization }\end{array}$ & $0.022 a$ & $0.018 a$ & $0.019 a$ & $0.021 a$ & $0.020 a$ & $0.021 a$ & 0.020 \\
\hline $\begin{array}{l}\text { Average clustering } \\
\text { coefficient }\end{array}$ & $0.327 a$ & $0.318 a$ & $0.309 b$ & $0.306 \mathrm{~b}$ & $0.306 \mathrm{~b}$ & $0.309 b$ & 0.313 \\
\hline Complexity & $9.64 a b$ & $9.94 a$ & $9.04 b$ & $8.72 \mathrm{c}$ & $8.67 c$ & $8.70 c$ & 9.12 \\
\hline Modularity & $0.349 c$ & $0.368 \mathrm{bc}$ & $0.393 a$ & $0.383 a b$ & $0.385 a b$ & $0.384 a b$ & 0.377 \\
\hline
\end{tabular}

\subsection{Nitrogen fertilizer-correlated OTUs and their co- occurrence patterns}

According to the results described above, we defined the root zone and its adjacent 1-cm soil compartment as the maize rhizosphere in the $\mathrm{NH}_{4}{ }^{+}$treatment, and the root zone and its adjacent $0.5-\mathrm{cm}$ soil compartment as the maize rhizosphere in the $\mathrm{NO}_{3}{ }^{-}$treatment. Four new bacterial networks were constructed for the $\mathrm{NH}_{4}{ }^{+}$rhizosphere, $\mathrm{NH}_{4}{ }^{+}$bulk soil, $\mathrm{NO}_{3}{ }^{-}$rhizosphere, and $\mathrm{NO}_{3}{ }^{-}$bulk soil (Fig. S1). Compared with the $\mathrm{NO}_{3}{ }^{-}$treatment, the $\mathrm{NH}_{4}{ }^{+}$treatment resulted in bacterial networks with more associations in both the rhizosphere and bulk soil (Fig. S1). To further explore the potential links between bacterial networks and soil residual fertilizer $\mathrm{N}$ in maize rhizosphere and bulk soil, we identified the "soil residual fertilizer $\mathrm{N}$-correlated microbes" showing strong $(r>0.8, p<0.01)$ correlations with soil residual fertilizer $\mathrm{N}$ in the networks (Table S5, Fig. 6). In the maize rhizosphere in the $\mathrm{NH}_{4}{ }^{+}$treatment, soil $\mathrm{N}$ derived from $\mathrm{NH}_{4}{ }^{+}$fertilizer was positively correlated with five bacterial OTUs (in Micrococcales, Burkholderiales, Sphingomonadales, and Rhodospirillales) and negatively correlated with 20 OTUs (mainly in Gemmatimonadales and Myxococcales) (Table S5). In the bulk soil, soil $\mathrm{N}$ derived from $\mathrm{NH}_{4}{ }^{+}$ fertilizer was positively correlated with one OTU (in Bacillales) and negatively correlated with four OTUs (in Sphingomonadales, Rhizobiales, and Legionellales). In the maize rhizosphere in the $\mathrm{NO}_{3}{ }^{-}$treatment, soil $\mathrm{N}$ derived from $\mathrm{NO}_{3}{ }^{-}$fertilizer was positively correlated with one OTU (in Bacillales) and negatively correlated with nine OTUs (mainly in Gemmatimonadales, Streptomycetales, Burkholderiales, and 
Solirubrobacterales). In the bulk soil, soil $\mathrm{N}$ derived from $\mathrm{NO}_{3}{ }^{-}$fertilizer was positively correlated with one OTU (in Enterobacteriales) and negatively correlated with two OTUs (in Rhizobiales and Gaiellales) (Table S5). These results indicated that $\mathrm{N}$ fertilizer, regardless of the $\mathrm{N}$ form, exerted more negative than positive effects on the growth of bacterial taxa. Bacterial networks in the maize rhizosphere were more sensitive than those in bulk soil, and were more sensitive to $\mathrm{NH}_{4}{ }^{+}$than to $\mathrm{NO}_{3}{ }^{-}$.

The "N fertilizer-correlated microbes" showed different patterns of co-occurrence (Fig. 6). The OTUs that were positively correlated with soil $\mathrm{N}$ derived from $\mathrm{N}$ fertilizers had more negative edges than positive edges in the bacterial networks in the maize rhizosphere and bulk soil. In contrast, the OTUs that were negatively correlated with soil $\mathrm{N}$ derived from $\mathrm{N}$ fertilizers had more positive edges than negative edges in the bacterial networks in maize rhizosphere and bulk soil (Fig. 6a and 6c). In the $\mathrm{NH}_{4}{ }^{+}$treatment, the rhizosphere OTUs that were positively correlated with soil $\mathrm{N}$ derived from $\mathrm{NH}_{4}{ }^{+}$fertilizer showed 95 positive correlations with other microbes mainly in the Frankiales, Xanthomonadales, Burkholderiales, Micrococcales, and Rhodospirillales orders, and 130 negative correlations with other microbes mainly in the Gemmatimonadales and Myxococcales orders (Fig. 6a). In bulk soil in the $\mathrm{NH}_{4}{ }^{+}$treatment, the OTUs that were positively connected with soil $\mathrm{N}$ derived from $\mathrm{NH}_{4}{ }^{+}$fertilizer showed three positive correlations with OTUs (in the Burkholderiales, Rhizobiales and an unknown order), and three negative correlations with the OTUs (in the Sphingomonadales, Xanthomonadales, and an unknown order) in the bacterial network (Fig. 6b). In the $\mathrm{NO}_{3}{ }^{-}$treatment, the rhizosphere OTUs that were positively correlated with soil $\mathrm{N}$ derived from $\mathrm{NO}_{3}{ }^{-}$fertilizer showed seven negative correlations with other microbes in the Chlorobiales, Rhizobiales, Solirubrobacterales, Rhodospirillales, Gemmatimonadales, and Sphingobacteriales (Fig. 6c). In the bulk soil in the $\mathrm{NO}_{3}{ }^{-}$treatments, the 123 OTUs that were positively correlated with soil $\mathrm{N}$ derived from $\mathrm{NO}_{3}{ }^{-}$fertilizer showed only one negative correlation (with an uncultured bacteria) in the network (Fig. 6d).

\section{Discussion}

\subsection{Nitrogen form and maize rhizosphere strongly affected soil chemical properties}

Our study showed that both the $\mathrm{N}$ form and the rhizosphere effect influenced the distribution patterns of various soil chemical properties with increasing distance from the roots. Compared with soil residual $\mathrm{NH}_{4}{ }^{+}$, the soil residual $\mathrm{NO}_{3}{ }^{-}$fluctuated more widely across the whole rhizobox after maize seedlings were harvested. This was mainly because $\mathrm{NO}_{3}{ }^{-}$is more mobile than $\mathrm{NH}_{4}{ }^{+}$[20]. In addition, plants were able to attract $\mathrm{NO}_{3}{ }^{-}$from outer compartments to the root surface, resulting in a relative enrichment of $\mathrm{NO}_{3}{ }^{-}$ fertilizer in the root zone. However, relative $\mathrm{NO}_{3}{ }^{-}$enrichment in the root zone was also observed in the $\mathrm{NH}_{4}{ }^{+}$treatment in our study. Considering that $\mathrm{NH}_{4}{ }^{+}$is generally immobile within soils and the $\mathrm{NH}_{4}{ }^{+}$ diffusion rate is lower than the crop uptake rate [20], we speculated that a portion of the $\mathrm{NH}_{4}{ }^{+}$fertilizer 
was nitrified into $\mathrm{NO}_{3}{ }^{-}$, and the $\mathrm{NO}_{3}{ }^{-}$derived from $\mathrm{NH}_{4}{ }^{+}$fertilizer moved from the outer compartments to the root zone.

The $\mathrm{pH}$ in the root zone was decreased by application of $\mathrm{NH}_{4}{ }^{+}$but increased by application of $\mathrm{NO}_{3}{ }^{-}$, compared with that in $\mathrm{CK}$. The distance of significant $\mathrm{pH}$ change under $\mathrm{NO}_{3}{ }^{-}$treatment was up to $0.5 \mathrm{~cm}$ from the root zone. Across the whole rhizobox, the soil pH was lower in the $\mathrm{NH}_{4}{ }^{+}$treatment than in $\mathrm{CK}$. In another study, $\mathrm{NO}_{3}{ }^{-}$-based fertilizer increased soil $\mathrm{pH}$ in the maize rhizosphere, while $\mathrm{NH}_{4}{ }^{+}$-based fertilizer decreased soil pH in both the rhizosphere and bulk soil [35]. In the present study, the variations in soil total $\mathrm{N}$ content were similar to those of fertilizer- $\mathrm{N}$, indicating that variations in soil total $\mathrm{N}$ content mainly depended on fertilizer- $\mathrm{N}$. Soil available $\mathrm{K}_{\text {and }} \mathrm{NH}_{4}{ }^{+} \mathrm{N}$ contents decreased sharply in the proximity of the roots in the present study, probably because both $\mathrm{K}^{+}$and $\mathrm{NH}_{4}{ }^{+}$are poorly mobile in soil [36]. In the present study, soil available $\mathrm{P}$ content did not vary across the rhizobox. Previous reports have shown that the depletion zone for $\mathrm{P}$ is usually $2-3 \mathrm{~mm}$ from the roots [4], so the depletion of soil available $\mathrm{P}$ by maize seedlings may not have been detected in the present study.

\subsection{Nitrogen form and maize rhizosphere influenced soil bacterial community diversity and composition}

Previous studies have shown that application of $\mathrm{N}$ fertilizers (including $\mathrm{NH}_{4} \mathrm{NO}_{3}$, urea, and $\mathrm{NO}_{3}{ }^{-}$) can inhibit soil bacterial diversity [37-39]. This may be because an increased inorganic $\mathrm{N}$ content reduces the competitiveness of microbes that are less tolerant to high osmotic potential and/or those that are able to fix $\mathrm{N}_{2}$ [40]. Consistent with those reports, the Shannon's index values were lower in the $\mathrm{NH}_{4}{ }^{+}$and $\mathrm{NO}_{3}{ }^{-}$ treatments than in CK. However, this inhibitory effect was detected only in the maize root zone, indicating a dual effect of $\mathrm{N}$ fertilizer and rhizosphere on soil microbes. While $\mathrm{N}$ fertilizer inputs alter microbial niches as discussed above, plant roots preferentially recruit beneficial members of the bacterial community to colonize the rhizosphere, thereby forming a rhizosphere that is more sensitive than bulk soil to changes in the environment [7-9]. We detected decreased bacterial alpha diversity in the proximity of roots in the $\mathrm{N}$-fertilized treatments. This "rhizosphere effect" was not detected in $\mathrm{CK}$, indicating that it was stimulated by $\mathrm{N}$ fertilization. Nitrogen affects the belowground distribution of plant photosynthates, and rhizodeposition is positively correlated with the $\mathrm{N}$ fertilization rate [41]. In the present study, the enhancement of maize shoot growth by $\mathrm{N}$ fertilization may have significantly affected the soil bacterial community structure and diversity.

Although $\mathrm{NH}_{4}{ }^{+}$and $\mathrm{NO}_{3}{ }^{-}$fertilizers had similar effects on bacterial alpha diversity, they had different effects on bacterial beta diversity (bacterial community structures and composition). These differences were more pronounced in the maize root zone and its adjacent $0.5-\mathrm{cm}$ soil compartment than in the outer compartments. This finding further indicated that maize roots play an essential role in selecting specific species that adapt to niche utilization [42]. The "rhizosphere effect" to shape root-associated bacterial communities varies with different $\mathrm{N}$ forms. Soil pH is the major driver of soil bacterial assembly. In this 
study, in the $\mathrm{NH}_{4}{ }^{+}$treatment, Burkholderiales was the dominant order in the maize root zone and 0$0.5 \mathrm{~cm}$ soil compartment. This order is known to dominate in low-pH and carboxylate-rich rhizospheres, where it metabolizes citrate and oxalate and ameliorates the effects of aluminum stress [10,43]. The genera specifically enriched within $0.5 \mathrm{~cm}$ of the maize root zone under $\mathrm{NH}_{4}{ }^{+}$compared with $\mathrm{CK}$ and $\mathrm{NO}_{3}{ }^{-}$were Acidibacter, Burkholderia, and Catenulispora, which are potentially beneficial acidophilic bacteria [44-46]. In the $\mathrm{NO}_{3}{ }^{-}$treatment, Sphingomonadales was the dominant order in the maize root zone and its adjacent $0.5-\mathrm{cm}$ soil compartment. This order is known to contribute to higher crop yield [37]. Furthermore, the genera Sphingomonas, Sphingobium, Azospirillum, and Novosphingobium were specifically enriched within $0.5 \mathrm{~cm}$ of the maize root zone in the $\mathrm{NO}_{3}{ }^{-}$treatment compared with $\mathrm{CK}$ and the $\mathrm{NH}_{4}{ }^{+}$treatment. These genera are plant growth-promoting rhizobacteria that favor nutrient-rich and higher-pH soils $[24,47]$. Therefore, in this study, the maize roots tended to recruit potentially beneficial bacteria with a higher tolerance to acid and aluminum to cope with decreased soil pH during $\mathrm{NH}_{4}{ }^{+}$ uptake, and to recruit growth-promoting microbes that prefer higher $\mathrm{pH}$ during $\mathrm{NO}_{3}{ }^{-}$uptake.

The bacterial communities in the $0-1 \mathrm{~cm}$ soil compartment under $\mathrm{NH}_{4}{ }^{+}$treatment and in the $0-0.5 \mathrm{~cm}$ soil compartment under $\mathrm{NO}_{3}{ }^{-}$treatment were more similar to those in the root zone $(0 \mathrm{~cm})$ but significantly differed from those in the outer compartments. Therefore, the "rhizosphere effect" on bacterial communities was not restricted to the root zone, but extended to $1 \mathrm{~cm}$ from the root zone under $\mathrm{NH}_{4}{ }^{+}$treatment and $0.5 \mathrm{~cm}$ from the root zone under $\mathrm{NO}_{3}{ }^{-}$treatment. Root exudates are selective factors that shape the structure of the rhizosphere microbiome [10]. The range of the "rhizosphere effect" is highly dependent on the flow of root exudates [28]. Previous studies have shown that root exudates can penetrate up to $8-14 \mathrm{~mm}$ into most upland soils [48-50], and the size of this range can be affected by soil structure and compaction, water status, and the activity of soil microbes [2]. In the present study, the rhizosphere effect had a larger range in the $\mathrm{NH}_{4}{ }^{+}$treatment than in the $\mathrm{NO}_{3}{ }^{-}$treatment. This may be because of changes in $\mathrm{pH}$ during the uptake of $\mathrm{NH}_{4}{ }^{+}$and $\mathrm{NO}_{3}{ }^{-}$by plants. Since soil $\mathrm{pH}$ is known to be negatively correlated with belowground carbon allocation [41], increased $\mathrm{pH}$ may decrease the range of the rhizosphere effect on microbiomes [4]. Therefore, applying $\mathrm{NH}_{4}{ }^{+}$may increase the range of the rhizosphere effect due to reduced soil $\mathrm{pH}$.

\subsection{Nitrogen form and maize rhizosphere influenced bacterial co-occurrence patterns}

Microbial co-occurrence patterns reflect direct and indirect interactions among microbial taxa coexisting in environmental samples, and can provide insights into bacterial communities' functional roles and/or the environmental niches occupied by microorganisms [51]. In the present study, we found that bacterial networks were more complex in the $\mathrm{NH}_{4}{ }^{+}$treatment than in $\mathrm{CK}$, whereas those in the $\mathrm{NO}_{3}{ }^{-}$treatment were less complex than those in CK. Unfavorable soil environmental conditions (acidity, nutrient deficiency) promote both co-operation and competition in bacterial networks. Accordingly, microbial networks were 
found to be less complex under limed and $\mathrm{N}$-fertilized conditions than under control conditions [52]. In this study, $\mathrm{NO}_{3}{ }^{-}$fertilization resulted in less complex bacterial networks in all soil compartments, probably because $\mathrm{NO}_{3}{ }^{-}$application provided more favorable conditions in terms of higher soil $\mathrm{pH}$ and $\mathrm{N}$ nutrition. Although the $\mathrm{NH}_{4}{ }^{+}$treatment provided sufficient $\mathrm{N}$ in the soil environment, the soil $\mathrm{pH}$ was decreased to 4.5 due to $\mathrm{NH}_{4}{ }^{+}$absorption and nitrification. This may have enhanced niche sharing and intensified competition and cooperation among bacterial taxa [52]. The bacterial networks were more complex in the maize root zone and its adjacent soil compartments $(0.5-1 \mathrm{~cm})$ than in the outer compartments in both the $\mathrm{NH}_{4}{ }^{+}$and $\mathrm{NO}_{3}{ }^{-}$treatments, indicative of more complex bacterial networks in the maize rhizosphere than in bulk soil. Since roots act as a filter during the assembly of rhizosphere bacterial communities [12] and promote the development of niches populated by dominant taxa, it is reasonable for competition and cooperation to be stronger in the rhizosphere due to shared niches [53]. In contrast, microbes in bulk soil occupy heterogeneous and disconnected habitats [53]. Whereas some long-term studies considering the rhizosphere community as a subset of the bulk soil community have detected less complex network structures in the rhizosphere than in bulk soil [12,54], our greenhouse study revealed an instant effect of plant roots on rhizosphere bacterial networks.

\subsection{Soil residual fertilizer $\mathrm{N}$-correlated OTUs in bacterial networks}

In this study, we defined the soil compartment $0.5 \mathrm{~cm}$ and $1 \mathrm{~cm}$ from the root zone as the rhizosphere under $\mathrm{NO}_{3}{ }^{-}$and $\mathrm{NH}_{4}{ }^{+}$treatment, respectively. We found that more bacterial OTUs were strongly correlated with soil residual $\mathrm{N}$ derived from $\mathrm{NH}_{4}{ }^{+}$fertilizer, and formed more complexed networks with other microbes under $\mathrm{NH}_{4}{ }^{+}$treatment compared with $\mathrm{NO}_{3}{ }^{-}$in both maize rhizosphere and bulk soil. This indicated that bacterial growth and associations were more sensitive to $\mathrm{NH}_{4}{ }^{+}$fertilizer than to $\mathrm{NO}_{3}{ }^{-}$ fertilizer. The strong positive correlations between OTUs from Burkholderiales / Rhodospirillales and soil residual $\mathrm{N}$ derived from $\mathrm{NH}_{4}{ }^{+}$fertilizer in the present study provide insight into a carbon- $\mathrm{N}$ coupling mechanism, since these correlated microbes have been reported to use root exudates as carbon sources and to degrade organic materials $[10,55]$. We also found that the OTUs which positively correlated with soil residual $\mathrm{N}$ derived from $\mathrm{NH}_{4}{ }^{+}$fertilizer had the most positive correlations with OTUs from Frankiales, indicating that these OTUs interacted with members of the Frankiales to efficiently colonize the maize rhizosphere. Our results show that $\mathrm{N}$ fertilizer, regardless of the $\mathrm{N}$ form, had stronger negative effects on bacterial networks in the maize rhizosphere than in bulk soil. This may be attributed to $\mathrm{pH}$ changes and the accumulated $\mathrm{NH}_{4}{ }^{+}-\mathrm{N}$ and $\mathrm{NO}_{3}{ }^{-} \mathrm{N}$ contents, as most bacterial taxa exhibit narrow tolerance to changes in $\mathrm{pH}$ [56], and some $\mathrm{N}$-cycling microbes may be inhibited by increasing $\mathrm{NH}_{4}{ }^{+}-\mathrm{N}^{-}$and $\mathrm{NO}_{3}{ }^{-}-\mathrm{N}$ contents $[26,57]$. For example, in the present study, OTUs from the Myxococcales were negatively correlated with soil residual $\mathrm{N}$ derived from $\mathrm{NH}_{4}{ }^{+}$fertilizer in the maize rhizosphere. Myxococcales are known to be inhibited by chemical $\mathrm{N}$ fertilizer due to soil acidification [58]. The OTUs from the 
Streptomycetales were negatively correlated with soil residual $\mathrm{N}$ derived from $\mathrm{NO}_{3}{ }^{-}$fertilizer. Members of this order participate in heterotrophic nitrification, which is inhibited by increased $\mathrm{NO}_{3}{ }^{-}{ }^{-} \mathrm{N}$ content [59].

\section{Conclusion}

The maize rhizosphere and the $\mathrm{N}$ form affected the spatial distribution of soil chemical properties, bacterial communities, and bacterial co-occurrence patterns along a lateral distance from maize roots in an acidic red soil. The rhizosphere effect showed different responses to different $\mathrm{N}$ forms. The range of the rhizosphere effect was larger under $\mathrm{NH}_{4}{ }^{+}$treatment than under $\mathrm{NO}_{3}{ }^{-}$treatment. Because of changes in $\mathrm{pH}$ during the uptake of $\mathrm{NH}_{4}{ }^{+}$and $\mathrm{NO}_{3}{ }^{-}$, plant roots tended to recruit $\mathrm{N}$-form-specific taxa, and this shifted the bacterial co-occurrence patterns. The results of this study increase our understanding of how the $\mathrm{N}$ form and rhizosphere interactively affect soil chemical properties, bacterial diversity, and bacterial community composition, and have implications for controlling soil microbial diversity and ecological functions in agricultural ecosystems.

\section{Declarations}

\section{Acknowledgments}

We thank Prof. Zhongjun Jia for comments on the manuscript, and Ms. Deling Sun and Qiaojun Fan for technical support with the ${ }^{15} \mathrm{~N}$ abundance analyses. We thank Jennifer Smith, PhD, from Liwen Bianji, Edanz Group China (www.liwenbianji.cn/ac), for editing the English text of a draft of this manuscript.

\section{Author's contributions}

X.Q.Z. conceived the study and designed the experiment. H.Q.Z performed the experiment, analyzed the data, and wrote the first draft of the manuscript. X.Q.Z., Y.S., Y.L., and R.F.S. interpreted the data and revised the manuscript. All authors read and approved the final manuscript.

\section{Funding}

This work was supported by the Strategic Priority Research Program of the Chinese Academy of Sciences (No. XDA24020104), the National Natural Science Foundation of China (No. 31672229), and the National Key Research and Development Program of China (No. 2019YFC1803704).

\section{Availability of data and materials}

The raw sequence reads have been deposited at the NCBI sequence reads archive (SRA) under the accession number SRP250372. 


\section{Ethics approval and consent to participate}

Not applicable.

\section{Consent for publication}

Not applicable.

\section{Competing interests}

The authors declare that they have no competing interests.

\section{References}

1. Kuzyakov Y, Blagodatskaya E. Microbial hotspots and hot moments in soil: concept \& review. Soil Biol Biochem. 2015;83:184-199.

2. Bais HP, Weir TL, Perry LG, Gilroy S, Vivanco JM. The role of root exudates in rhizosphere interactions with plants and other organisms. Annu Rev Plant Biol. 2006; 57:233-266.

3. Moritsuka N, Yanai J, Kosaki T. Effect of plant growth on the distribution and forms of soil nutrients in the rhizosphere. Soil Sci Plant Nutr. 2000;46:439-447.

4. Kuzyakov Y, Razavi BS. Rhizosphere size and shape: Temporal dynamics and spatial stationarity. Soil Biol Biochem. 2019;135:343-360.

5. Liu C, Gong X, Dang K, Li J, Yang P, Gao X, et al. Linkages between nutrient ratio and the microbial community in rhizosphere soil following fertilizer management. Environ Res. 2020;184: 109261.

6. Wan W, Tan J, Wang Y, Qin Y, He H, Wu H, et al. Responses of the rhizosphere bacterial community in acidic crop soil to $\mathrm{pH}$ : Changes in diversity, composition, interaction, and function. Sci Total Environ. 2020;700:134418.

7. Fitzpatrick CR, Copeland J, Wang PW, Guttman DS, Kotanen PM, Johnson MTJ. Assembly and ecological function of the root microbiome across angiosperm plant species. P Natl Acad Sci USA. 2018;115:E1157-E1165.

8. Hu L, Robert CAM, Cadot S, Zhang X, Ye M, Li B, et al. Root exudate metabolites drive plant-soil feedbacks on growth and defense by shaping the rhizosphere microbiota. Nat Commun. 2018;9:2738.

9. Edwards J, Johnson C, Santos-Medellín C, Lurie E, Podishetty NK, Bhatnagar S, et al. Structure, variation, and assembly of the root-associated microbiomes of rice. P Natl Acad Sci USA. 2015;112: E911-E920.

10. Sasse J, Martinoia E, Northen T. Feed your friends: Do plant exudates shape the root microbiome? Trends Plant Sci. 2018;23:25-41. 
11. Jiang Y, Li S, Li R, Zhang J, Liu Y, Lv L, et al. Plant cultivars imprint the rhizosphere bacterial community composition and association networks. Soil Biol Biochem. 2017;109:145-155.

12. Fan $\mathrm{K}$, Weisenhorn $\mathrm{P}$, Gilbert JA, Chu $\mathrm{H}$. Wheat rhizosphere harbors a less complex and more stable microbial co-occurrence pattern than bulk soil. Soil Biol Biochem. 2018;125:251-260.

13. von Uexküll HR, Mutert E. Global extent, development and economic impact of acid soils. Plant Soil. 1995;171:1-15.

14. Zhao XQ, Shen RF. Aluminum-nitrogen interactions in the soil-plant system. Front Plant Sci. 2018; 9:807.

15. Fageria NK; Baligar VC. Improving nutrient use efficiency of annual crops in Brazilian acid soils for sustainable crop production. Commun Soil Sci Plant Anal. 2001;32,1303-1319.

16. Zhu ZL, Chen DL. Nitrogen fertilizer use in China - Contributions to food production, impacts on the environment and best management strategies. Nutr Cycl Agroecosys. 2002;63:117-127.

17. Guo JH, Liu XJ, Zhang Y, Shen JL, Han WX, Zhang WF, et al. Significant acidification in major Chinese croplands. Science 2010;327:1008-1010.

18. Ollivier J, Towe S, Bannert A, Hai B, Kastl E, Meyer A, et al. Nitrogen turnover in soil and global change. FEMS Microbiol Ecol. 2011; 78:3-16.

19. Wang GH, Zhou KQ, Jin J, Pan XW, Liu XB. Effects of different $\mathrm{N}$ sources on $\mathrm{N}$ nutrient and microbial distribution across soybean rhizosphere. Soil Sci Plant Nutr. 2003;49:817-823.

20. Li SX, Wang ZH, Stewart BA. Responses of crop plants to ammonium and nitrate N. Adv Agron. 2013;118:205-397.

21. Garnett T, Plett D, Conn V, Conn S, Rabie H, Rafalski JA, et al. Variation for $\mathrm{N}$ uptake system in maize: genotypic response to N supply. Front Plant Sci. 2015;6:936.

22. Huang S, Zhang WJ, Yu XC, Huang QR. Effects of long-term fertilization on corn productivity and its sustainability in an Ultisol of southern China. Agr Ecosyst Envrion. 2010;138: 44-50.

23. Zhang HM, Wang BR, Xu MG, Fan TL. Crop yield and soil responses to long-term fertilization on a red soil in southern China. Pedosphere. 2009;19:199-207.

24. Peiffer JA, Spor A, Koren O, Jin Z, Tringe SG, Dangl JL, et al. Diversity and heritability of the maize rhizosphere microbiome under field conditions. P Natl Acad Sci USA. 2013;110:6548-6553.

25. Walters WA, Jin Z, Youngblut N, Wallace JG, Sutter J, Zhang W. Large-scale replicated field study of maize rhizosphere identifies heritable microbes. P Natl Acad Sci USA. 2018;115:7368-7373.

26. Schmidt JE, Kent AD, Brisson VL, Gaudin ACM. Agricultural management and plant selection interactively affect rhizosphere microbial community structure and nitrogen cycling. Microbiome 2019;7:146.

27. Zhu S, Vivanco JM, Manter DK. Nitrogen fertilizer rate affects root exudation, the rhizosphere microbiome and nitrogen-use-efficiency of maize. Appl Soil Ecol. 2016;107:324-333.

28. Wang $X$, Chen $R$, Jing Z, Yao T, Feng Y, Lin X. Root derived carbon transport extends the rhizosphere of rice compared to wheat. Soil Biol Biochem. 2018;122:211-219. 
29. Chen L, Fang K, Zhou J, Yang ZP, Dong XF, Dai GH, et al. Enrichment of soil rare bacteria in root by an invasive plant Ageratina adenophora. Sci Total Environ. 2019;683:202-209.

30. Bolger AM, Lohse M, Usadel B. Trimmomatic: a flexible trimmer for Illumina sequence data. Bioinformatics. 2014; 30:2114-2120.

31. Reyon D, Tsai SQ, Khayter C, Foden JA, Sander JD, Joung JK. FLASH assembly of TALENs for highthroughput genome editing. Nat Biotechnol. 2012;30:460-465.

32. Caporaso JG, Kuczynski J, Stombaugh J, Bittinger K, Bushman FD, Costello EK, et al. QIIME allows analysis of high-throughput community sequencing data. Nat Methods. 2010;7:335-336.

33. Zhang HQ, Zhao XQ, Chen YL, Zhang LY, Shen RF. Case of a stronger capability of maize seedlings to use ammonium being responsible for the higher ${ }^{15} \mathrm{~N}$ recovery efficiency of ammonium compared with nitrate. Plant Soil. 2019;440:293-309.

34. Wagg C, Schlaeppi K, Banerjee S, Kuramae EE, van der Heijden MGA, Fungal-bacterial diversity and microbiome complexity predict ecosystem functioning. Nat Commun. 2019;10:4841.

35. Masud MM, Guo D, Li J, Xu R. Hydroxyl release by maize (Zea mays) roots under acidic conditions due to nitrate absorption and its potential to ameliorate an acidic Ultisol. J Soils Sediment. 2014;14:845-853.

36. Barber S, Walker J, Vasey EH. Mechanisms for movement of plant nutrients from soil and fertilizer to plant root. J Agr Food Chem. 1963;11:204-207.

37. Zhou J, Guan D, Zhou B, Zhao B, Ma M, Qin J, et al. Influence of 34-years of fertilization on bacterial communities in an intensively cultivated black soil in northeast China. Soil Biol Biochem. 2015;90:4251.

38. Ding J, Jiang X, Ma M, Zhou B, Guan D, Zhao B, et al. Effect of 35 years inorganic fertilizer and manure amendment on structure of bacterial and archaeal communities in black soil of northeast China. Appl Soil Ecol. 2016;105:187-195.

39. Wang Q, Jiang X, Guan D, Wei D, Zhao B, Ma M, et al. Long-term fertilization changes bacterial diversity and bacterial communities in the maize rhizosphere of Chinese Mollisols. Appl Soil Ecol. 2018;125:88-96.

40. Kolb W, Martin P. Influence of nitrogen on the number of $\mathrm{N}_{2}$-fixing and total bacteria in the rhizosphere. Soil Biol Biochem. 1988;20:221-225.

41. Liu Y, Ge T, Zhu Z, Liu S, Luo Y, Li Y, et al. Carbon input and allocation by rice into paddy soils: A review. Soil Biol Biochem. 2019;133:97-107.

42. Chen Y, Sun R, Sun T, Liang Y, Jiang Y, Sun B. Organic amendments shift the phosphorus-correlated microbial co-occurrence pattern in the peanut rhizosphere network during long-term fertilization regimes. Appl Soil Ecol. 2018;124:229-239.

43. Lian T, Ma Q, Shi Q, Cai Z, Zhang Y, Cheng Y, et al. High aluminum stress drives different rhizosphere soil enzyme activities and bacterial community structure between aluminum-tolerant and aluminumsensitive soybean genotypes. Plant Soil. 2019;440:409-425. 
44. Falagán C, Johnson DB. Acidibacter ferrireducens nov., sp. nov.: an acidophilic ferric iron-reducing gammaproteobacterium. Extremophiles. 2014;18:1067-1073.

45. Paungfoo-Lonhienne C, Lonhienne TGA, Yeoh YK, Webb RI, Lakshmanan P, Chan CX, et al. A new species of Burkholderia isolated from sugarcane roots promotes plant growth. Microb Biotechnol. 2013;7:142-154.

46. Chen Y, Bonkowski M, Shen Y, Griffiths BS, Jiang Y, Wang X, et al. Root ethylene mediates rhizosphere microbial community reconstruction when chemically detecting cyanide produced by neighbouring plants. Microbiome. 2020;8:4.

47. Wang R, Wei S, Jia P, Liu T, Hou D, Xie R, et al. Biochar significantly alters rhizobacterial communities and reduces $\mathrm{Cd}$ concentration in rice grains grown on Cd-contaminated soils. Sci Total Environ. 2019;676:627-638.

48. Sauer D, Kuzyakov Y, Stahr K. Spatial distribution of root exudates of five plant species as assessed by ${ }^{14} \mathrm{C}$ labeling. J Plant Nutr Soil Sc. 2006;169:360-362.

49. Qiao Y, Miao S, Li N, Han X, Zhang B. Spatial distribution of rhizodeposit carbon of maize (Zea mays) in soil aggregates assessed by multiple pulse ${ }^{13} \mathrm{C}$ labeling in the field. Plant Soil. 2014;375:317-329.

50. Hafner S, Wiesenberg GLB, Stolnikova E, Merz K, Kuzyakov Y. Spatial distribution and turnover of root-derived carbon in alfalfa rhizosphere depending on top- and subsoil properties and mycorrhization. Plant Soil. 2014;380:101-115.

51. Barberán A, Bates ST, Casamayor EO, Fierer N. Using network analysis to explore co-occurrence patterns in soil microbial communities. ISME J. 2012;6:343-351.

52. Ma B, Lv X, Cai Y, Chang SX, Dyck MF. Liming does not counteract the influence of long-term fertilization on soil bacterial community structure and its co-occurrence pattern. Soil Biol Biochem. 2018;123:45-53.

53. Shi S, Nuccio EE, Shi ZJ, He Z, Zhou J, Firestone MK. The interconnected rhizosphere: High network complexity dominates rhizosphere assemblages. Ecol Lett. 2016;19:926-936.

54. Mendes LW, Kuramae EE, Navarrete AA, van Veen JA, Tsai SM. Taxonomical and functional microbial community selection in soybean rhizosphere. ISME J. 2014;8:1577-1587.

55. Long $X$, Yao H, Huang Y, Wei W, Zhu Y. Phosphate levels influence the utilisation of rice rhizodeposition carbon and the phosphate-solubilising microbial community in a paddy soil. Soil Biol Biochem. 2018;118:103-114.

56. Rousk J, Bååth E, Brookes PC, Lauber CL, Lozupone C, Caporaso JG. Soil bacterial and fungal communities across a pH gradient in an arable soil. ISME J. 2010;4:1340-1351.

57. Sun R, Guo X, Wang D, Chu H. Effects of long-term application of chemical and organic fertilizers on the abundance of microbial communities involved in the nitrogen cycle. Appl Soil Ecol. 2015;95:171178.

58. Wang W, Wang N, Dang K., Dai W, Guan L, Wang B, et al. Long-term nitrogen application decreases the abundance and copy number of predatory myxobacteria and alters the myxobacterial community 
structure in the soil. Sci Total Environ. 2020;708:135114.

59. Li P, Zhang Y, Meng Q, Liu Y, Tuyiringire D, Chen Z, et al. Effects of trichloroethylene stress on the microbiological characteristics of Mollisol. Ecotox Environ Safe. 2019;184:109595.

\section{Figures}
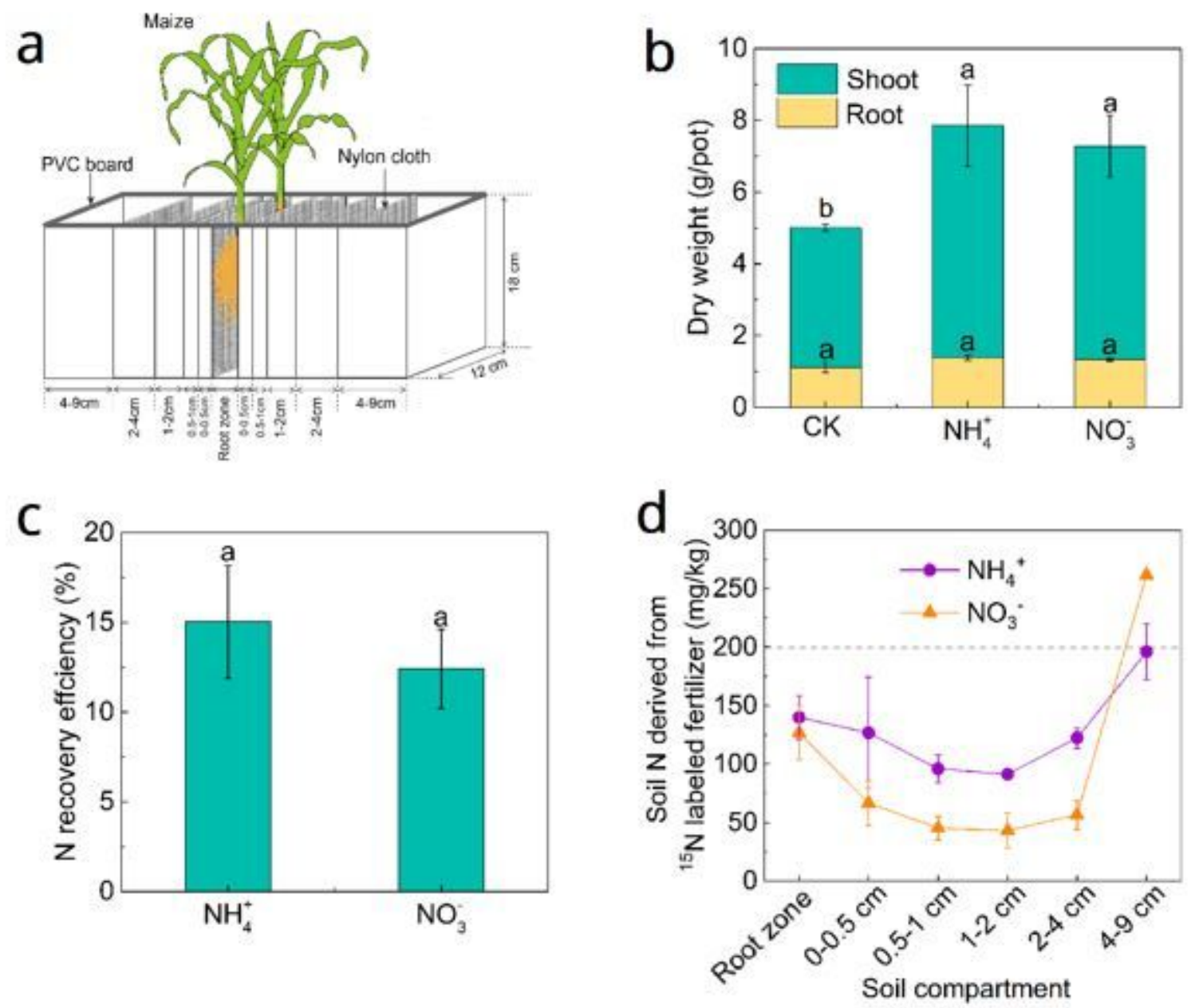

\section{Figure 1}

Schematic diagram of rhizobox (a), maize dry weight (b) and N-recovery efficiency (NRE) of maize seedlings (c), and soil residual $\mathrm{N}$ derived from $15 \mathrm{~N}$ labeled fertilizer (d). Maize seedlings were planted in central compartment, designated as root zone $(1 \mathrm{~cm}$ wide). Five compartments were arranged on each side of central compartment, with widths of $0.5 \mathrm{~cm}, 0.5 \mathrm{~cm}, 1 \mathrm{~cm}, 2 \mathrm{~cm}$, and $5 \mathrm{~cm}$ (corresponding to compartments $0-0.5 \mathrm{~cm}, 0.5-1 \mathrm{~cm}, 1-2 \mathrm{~cm}, 2-4 \mathrm{~cm}$, and $4-9 \mathrm{~cm}$, respectively). Maize seedlings were grown in rhizoboxes for 38 days. Data are means \pm standard deviation (SD). 

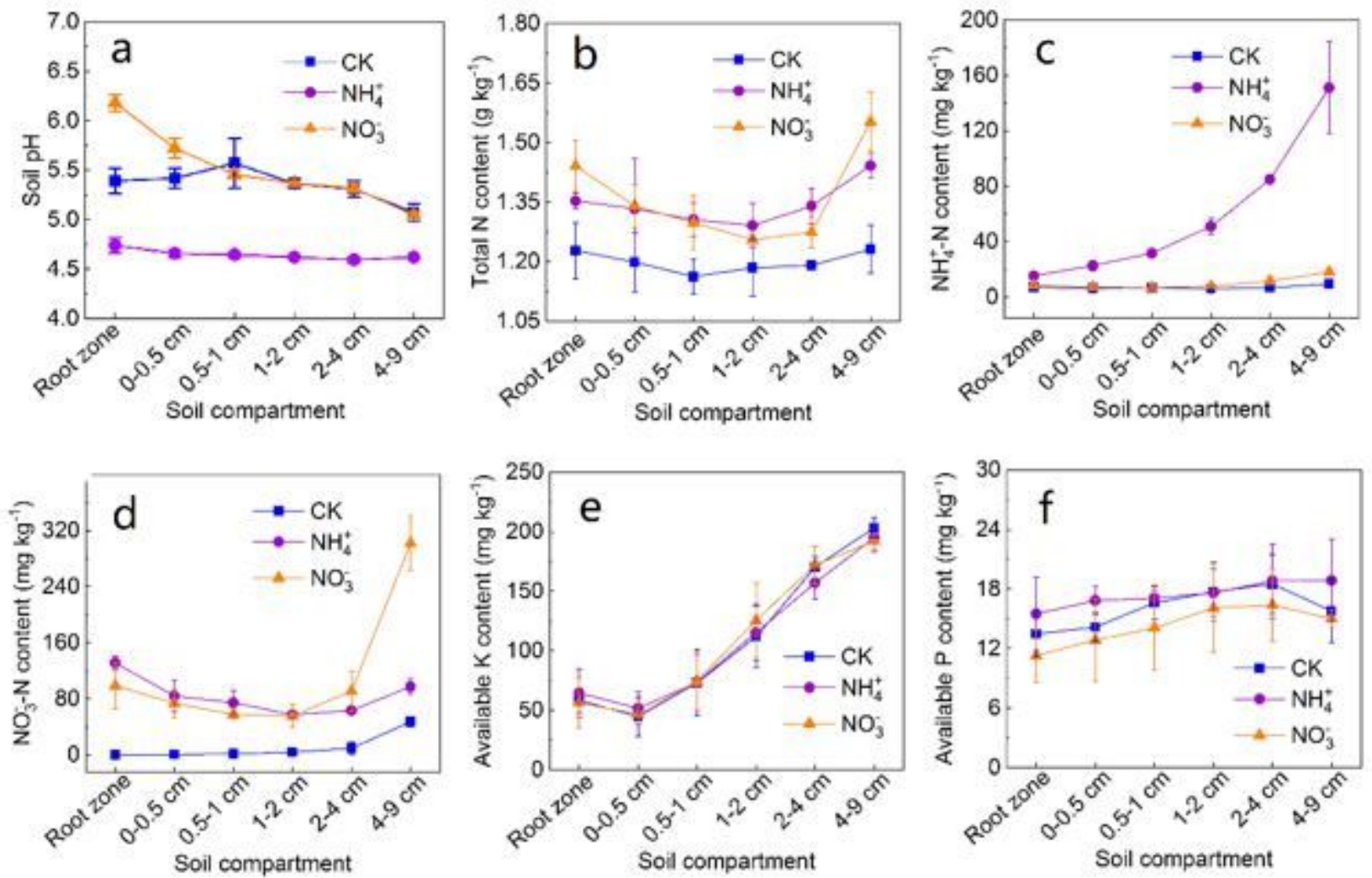

Figure 2

Soil chemical properties measured in different soil compartments under various $\mathrm{N}$-fertilizer treatments after maize seedlings were harvested. Maize seedlings were grown in rhizoboxes for 38 days. (a) Soil pH; (b) soil total $\mathrm{N}$ content; (c) soil ammonium-N (NH4+-N) content; (d) soil nitrate-N (NO3--N) content; (e) soil available K content; $(f)$ soil available $\mathrm{P}$ content. Data are means \pm standard deviation (SD). 

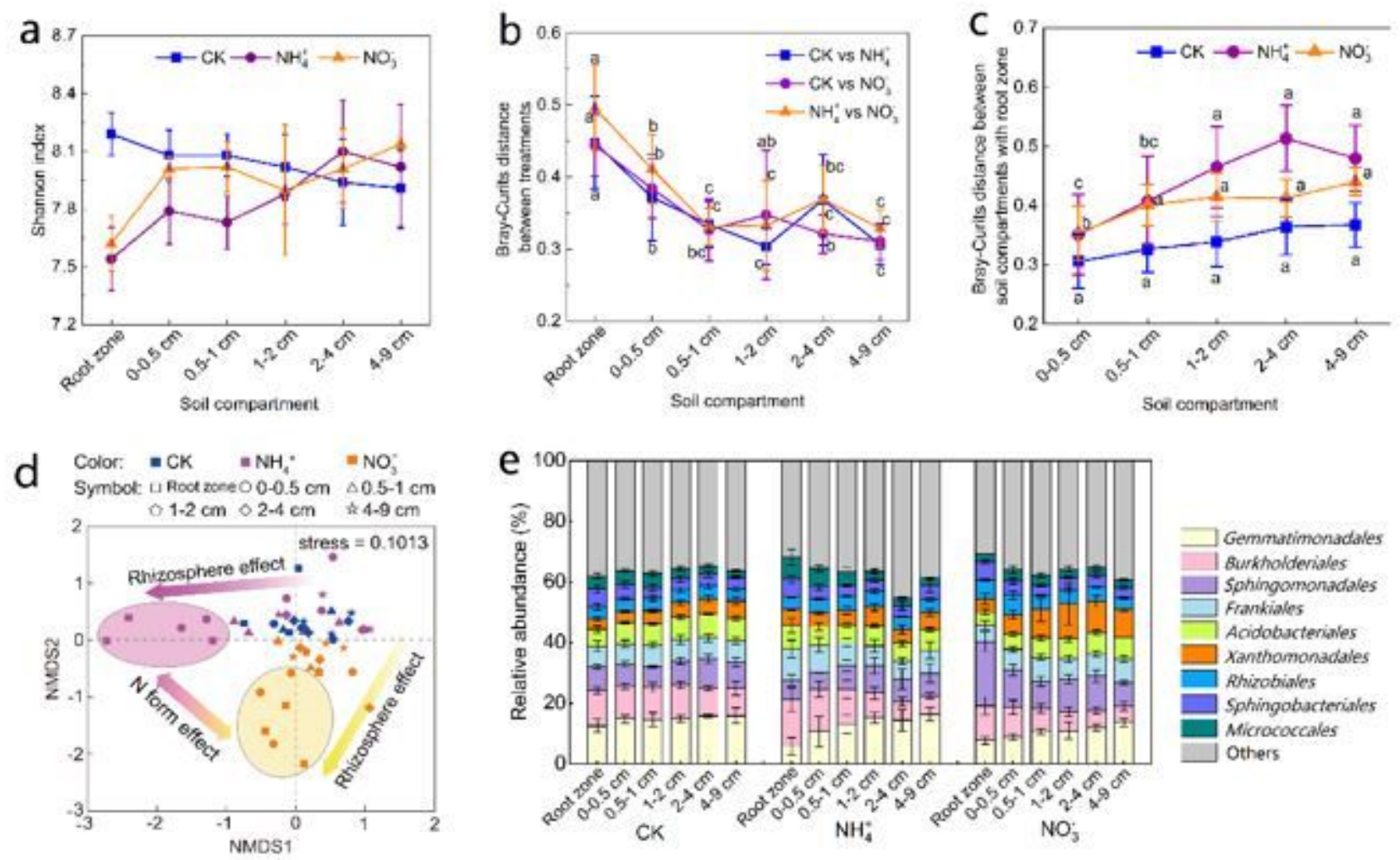

\section{Figure 3}

Overall diversity and changes in structure of soil bacterial communities under various $\mathrm{N}$-fertilizer treatments in different soil compartments after maize seedlings were harvested. Maize seedlings were grown in rhizoboxes for 38 days. (a) Alpha diversity (Shannon's index); (b) Bray-Curtis distance between $\mathrm{CK}$ and $\mathrm{NH} 4+, \mathrm{CK}$ and $\mathrm{NO}_{-}-$, and $\mathrm{NH} 4+$ and NO3- treatments in different soil compartments; (c) BrayCurtis distance between root zone soil and other soil compartments in $\mathrm{CK}$ and under $\mathrm{NH} 4+$ and $\mathrm{NO} 3-$ treatments; (d) non-metric multidimensional scaling (NMDS) analysis based on Bray-Curtis dissimilarity matrix; (e) relative abundance of major orders (top 10) in bacterial communities at different distances from roots in $\mathrm{CK}$ and under $\mathrm{NH} 4+$ and NO3- treatments. Different lowercase letters above lines indicate significant differences among different soil compartments for the same treatment $(p<0.05$, Duncan's multiple range test). 


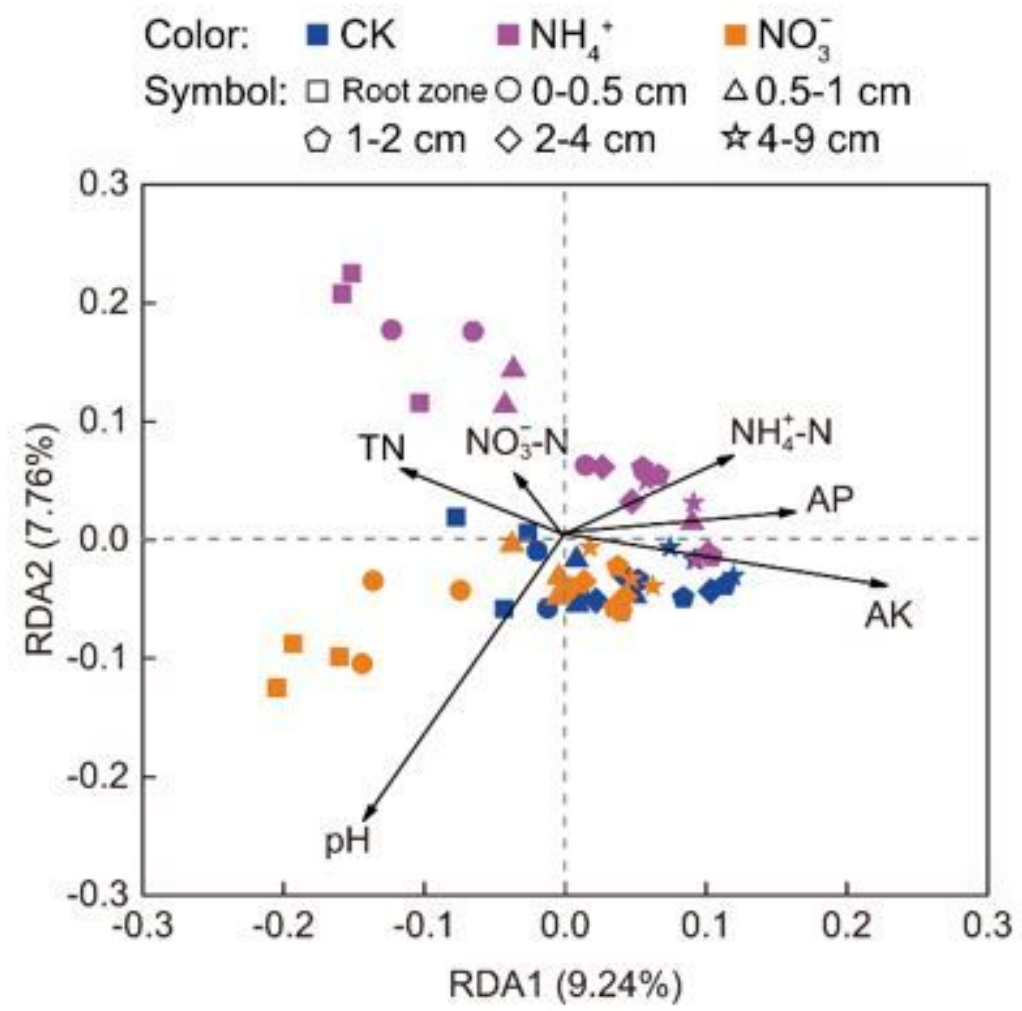

\section{Figure 4}

Ordination plot showing results of redundancy analysis (RDA), illustrating correlation between bacterial community structures and soil chemical properties across all soil samples in different soil compartments under various $\mathrm{N}$-fertilizer treatments. Position of arrow indicates direction of effect of soil chemical property on bacterial community structures, and length of arrow indicates strength of effect. 


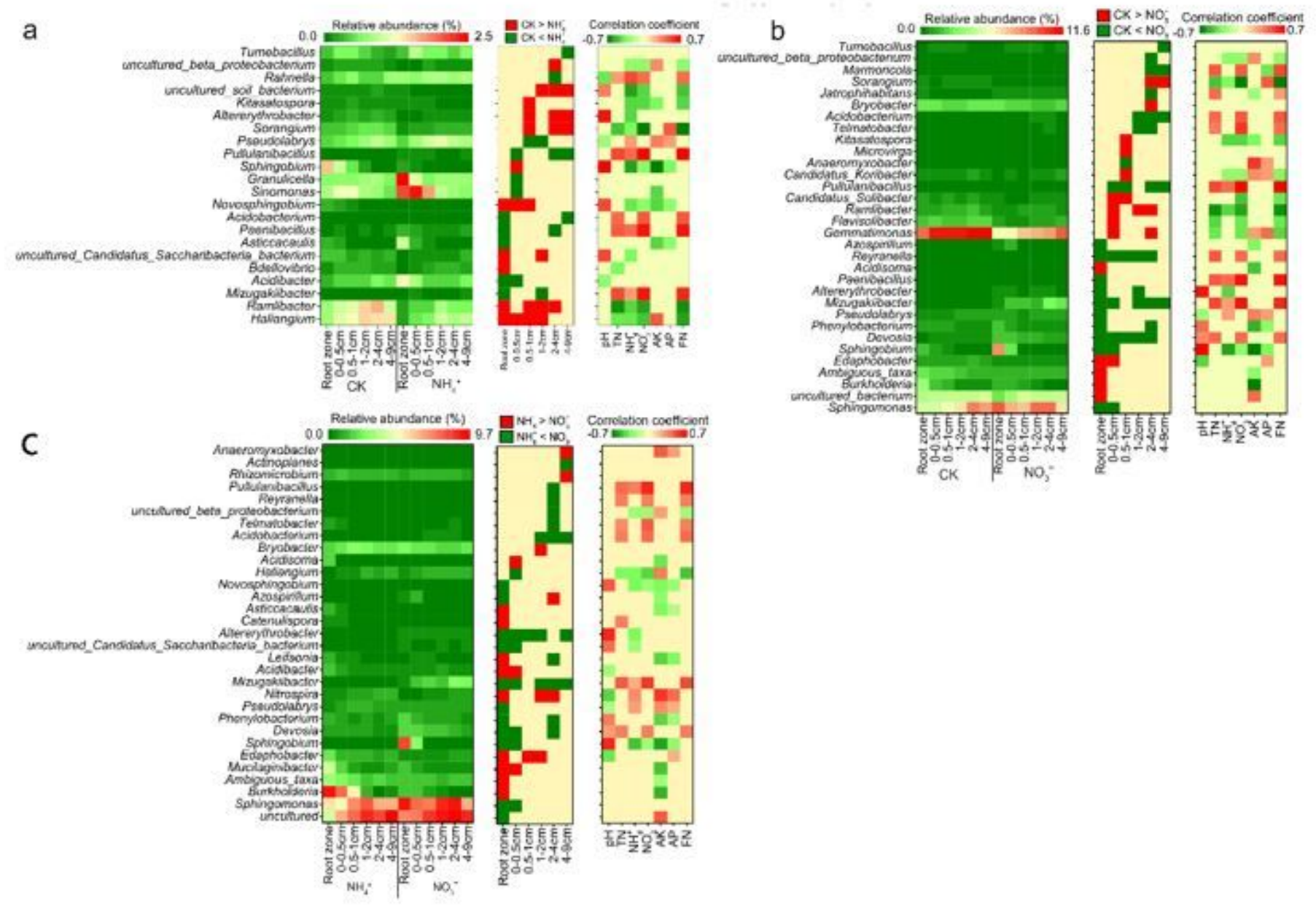

Figure 5

Heatmap of abundance of bacterial genera (left) and differences in bacterial genera (middle) highlighting significant differences $(\mathrm{p}<0.05)$ between $\mathrm{CK}$ and $\mathrm{NH} 4+(a)$, $\mathrm{CK}$ and NO3- (b), and NH4+ and NO3- (c) treatments in different soil compartments. Panel on right shows results of Pearson's correlation analysis of relative abundance of these genera vs. soil chemical properties. To simplify heatmap, only genera with relative abundance $>0.1 \%$ are shown. $\mathrm{FN}$ : soil residual $\mathrm{N}$ derived from $15 \mathrm{~N}$ labeled fertilizers; $\mathrm{TN}$ : total $\mathrm{N}$; AK: available K; AP: available P. 

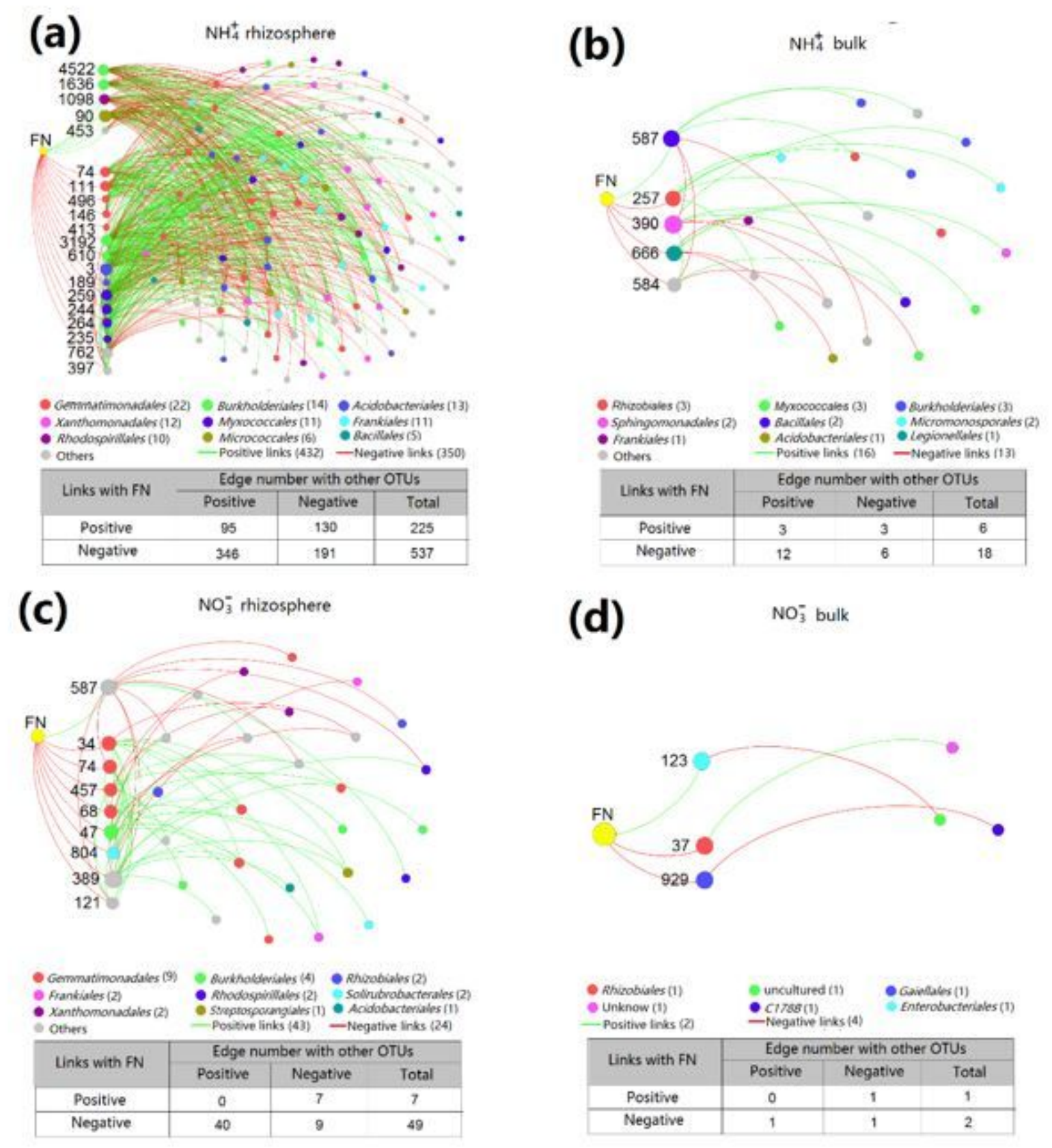

\section{Figure 6}

Connections of specific NH4+ and NO3- fertilizer-correlated OTUs with other OTUs in rhizosphere and bulk soil network. Maize root zone and its adjacent $1 \mathrm{~cm}$ soil compartments were defined as the rhizosphere under $\mathrm{NH} 4+$ treatment, and maize root zone and its adjacent $0.5 \mathrm{~cm}$ soil compartments were defined as the rhizosphere under NO3- treatment. (a) Connections of NH4+ fertilizer-correlated OTUs in the maize rhizosphere network; (b) connections of NH4+ fertilizer-correlated OTUs in the bulk soil network; (c) connections of NO3-fertilizer-correlated OTUs in the maize rhizosphere network; (d) connections of NO3-fertilizer-correlated OTUs in the bulk soil network. Only strong correlations $(r>0.8, p<0.1)$ are shown. Green and red edges indicate positive and negative interactions, respectively. 


\section{Supplementary Files}

This is a list of supplementary files associated with this preprint. Click to download.

- Additionalfile.docx 